\title{
FAKTOR-FAKTOR SISTEM INTERAKSI YANG MEMPENGARUHI EFEKTIFITAS IKLAN ONLINE
}

\author{
Ilham Aji Pratomo dan Dadan Hardianto \\ Fakultas Ilmu Komputer, Universitas Indonesia, Depok, Indonesia \\ dadan@cs.ui.ac.id
}

\begin{abstract}
Abstrak
Penelitian ini mengkhususkan pada efektifitas iklan online dengan memanfaatkan sudut pandang ilmu sistem interaksi atau lazim disebut human-computer interaction. Pendekatan yang dipergunakan dalam pengukuran efektifitas adalah jumlah klik. Tujuan dari penelitian ini adalah mengetahui faktor-faktor apa saja yang berkaitan dengan ilmu sistem interaksi yang mempengaruhi efektifitas tersebut. Metode yang dipergunakan adalah metode kuantitatif dengan populasi civitas akademika Universitas Indonesia. Setelah melakukan penelitian ini, peneliti menemukan bahwa faktor-faktor tersebut berpengaruh besar terhadap efektifitas iklan online sesuai dengan pendekatan jumlah klik yang diterapkan pada penelitian ini.
\end{abstract}

Kata kunci: efektifitas iklan, human-computer interaction, iklan online.

\section{Pendahuluan}

Perkembangan jumlah pengguna internet di Indonesia selama 8 tahun terakhir menunjukkan peningkatan yang sangat pesat. Tercatat bahwa jika pada awal tahun 2000 jumlah pengguna internet di Indonesia hanya berjumlah tidak lebih dari 1,9 juta pengguna, maka pada akhir tahun 2007 diperkirakan telah ada 25 juta pengguna (Asosiasi Penyelengara Jasa Internet Indonesia 2007). Dengan pertumbuhan ini, berarti pada setiap tahunnya, terdapat peningkatan jumlah pengguna sebanyak 3,3 juta. Hal ini membuat internet mulai dilihat sebagai sebuah media yang potensial untuk dimanfaatkan sebagai sarana beriklan.

Dibandingkan dengan media lain seperti televisi, internet menawarkan tarif yang relatif lebih rendah untuk jangka waktu pemasangan yang lebih lama. Jika dengan biaya 20 juta rupiah, seorang pengiklan hanya dapat menampilkan iklan satu slot selama dua kali penayangan. Sebaliknya, dengan biaya yang sama, pengiklan dapat memasang iklan selama berminggu-minggu pada internet.

Sejak awal kemunculannya, iklan online semakin mudah ditemui di internet. Bentuknya pun semakin beragam. Jika pada awalnya, iklan hanya berupa banner statis biasa yang mirip seperti spanduk, maka saat ini sudah ada iklan yang dapat muncul pada layar dengan window tersendiri ( $p o p$ up). Perkembangan ini juga mencakup persebarannya. Saat ini, hampir pada semua situs terdapat iklan mulai dari situs berita, situs toko online, sampai situs pribadi.

Dengan usia yang belum sampai dua dekade, iklan online merupakan bidang yang relatif masih muda sehingga memerlukan banyak studi lebih lanjut. Studi ini penting untuk memaksimalkan performa serta efektifitas iklan online itu sendiri.

Namun, perkembangan ini ternyata mulai membawa ketidaknyamanan dari pengguna internet yang dalam konteks ini adalah para calon konsumen. Hal ini tentu saja berpotensi menimbulkan dampak buruk bagi iklan itu sendiri.

Penelitian ini bertujuan untuk mengetahui faktor-faktor apa saja yang mempengaruhi efektifitas iklan online. Faktor faktor yang dibahas pada penelitian ini adalah faktor-faktor yang berkaitan dengan ilmu sistem interaksi. Dengan diketahuinya faktor-faktor tersebut, penulis berharap dapat menyumbangkan acuan-acuan dalam pembuatan sebuah iklan online agar menghasilkan iklan online yang efektif.

Pada penelitian ini, akan dilakukan pengujian terhadap faktor-faktor yang dianggap berpengaruh terhadap efektifitas iklan online. Pada saat wawancara, penulis memberikan pertanyaan yang berkaitan seputar iklan online dan hal-hal yang mempengaruhi efektifitas iklan online yang mereka tangani selama ini. Informasi yang didapat dari wawancara selanjutnya akan dijadikan basis pengujian untuk eksperimen yang akan dilakukan.

Dari faktor-faktor tersebut, akan dibuat iklan fiktif sesuai faktor tersebut. Semua iklan tersebut 
akan diuji melalui sebuah eksperimen yang berbentuk kuisioner online. Pada kuisioner online tersebut, responden akan diminta untuk melihat sejumlah halaman web yang direkayasa oleh penulis lalu responden tersebut diminta untuk menjawab sejumlah pertanyaan kemudian responden diminta untuk mengklik satu iklan pada setiap faktor.

Eksperimen ini berupa simulasi kuisioner yang dilakukan secara online di http://ilhamajipratomo.web.id/TA. Peneliti menyewa space kepada sebuah perusahaan webhost untuk dapat menjalankan kuisioner tersebut.

Dari data hasil kuisioner tersebut, penulis akan melakukan uji statistik untuk melihat fakta yang dapat diambil sehingga dapat mencapai tujuan dari penelitian ini seperti telah dikemukakan di atas.

\section{Landasan Teori}

\subsection{Iklan}

Iklan merupakan bentuk komunikasi berbayar yang bersifat non-personal yang bertujuan untuk memberi informasi tentang sebuah organisasi, produk, layanan, atau ide dari sebuah sponsor tertentu. Alasan disebut berbayar adalah karena umumnya, ruang maupun waktu bagi sebuah iklan merupakan sesuatu yang harus dibayar. Alasan sifat dari iklan yang non-personal adalah karena umumnya target dari sebuah iklan adalah orang banyak dan melibatkan media massa [1]. Iklan sangat erat kaitannya dengan pemasaran. Iklan merupakan salah satu bagian dari promotional mix yang paling sering digunakan.

Iklan dapat memiliki tujuan yang berbeda-beda satu dengan yang lainnya. Hal ini disebabkan oleh perbedaan tujuan promosi dari setiap perusahaan. Namun, secara garis besar, tujuan iklan terbagi ke dalam dua kelompok. Tujuan yang pertama adalah tujuan yang berkaitan dengan penjualan dan yang kedua adalah tujuan yang berkaitan dengan pembangunan awareness atau citra positif dari perusahaan maupun produk atau jasa yang diiklankan.

Sebagai salah satu bagian dari proses pemasaran, iklan sangat erat kaitannya dengan konsumen. Salah satu kesuksesan iklan dapat ditentukan oleh keberhasilan dalam membuat konsumen menerima iklan tersebut sesuai tujuannya. Pada masa lalu, terdapat strategi pemasaran yang disebut mass-market strategy. Strategi pemasaran ini dikenal sebagai strategi pemasaran yang cenderung membuat produk atau jasa yang dinilai dapat memuaskan semua orang.

Ternyata strategi pemasaran mass-market tidak cocok diterapkan kepada konsumen. Oleh karena itu, strategi ini perlahan mulai ditinggalkan. Sebagai gantinya, muncullah strategi pemasaran yang memperhatikan segmen pasar. Metode yang paling umum dimanfaatkan sebagai dasar segmentasi adalah demografis. Metode ini membagi konsumen berdasarkan data demografi seperti usia, jenis kelamin, suku dan pekerjaan. Metode ini memiliki keuntungan yaitu tingginya tingkat ketersediaan informasi maupun data demografi yang tersebar di berbagai sumber. Iklan sebagai salah satu komponen pemasaran dengan sendirinya memiliki hubungan yang erat dengan konsep ini. Hal ini merupakan konsekuensi dari keberadaan konsumen sebagai target dari iklan.

\subsubsection{Iklan Online}

Beberapa model bisnis yang tercipta dengan memanfaatkan internet telah diterapkan. Dua contoh modelnya ialah Business to Business dan Business To Customer. Model pertama ialah Business to Business, sering disingkat menjadi $B 2 B$. Model ini memanfaatkan internet sebagai sarana penghubung antar perusahaan. Dengan model ini, sebuah perusahaan dapat berbagi informasi yang berguna dengan perusahaan lain. Misalnya, produsen pelumas bekerja sama dengan produsen parfum mobil untuk meningkatkan penjualan mereka dengan cara saling bertukar informasi via internet.

Model bisnis yang kedua ialah Business to Customer. Business To Customer atau lazim disebut $B 2 C$ merupakan penerapan internet sebagai penghubung perusahaan dengan konsumennya. Misalnya, sebuah produsen pelumas kendaraan membuat situs web mereka yang mencantumkan keterangan tentang produk mereka serta memungkinkan pembelian secara online. Fitur seperti itu dapat memberikan manfaat bagi konsumen mereka maupun perusahaan itu sendiri.

Iklan online memiliki kelebihan dibandingkan iklan pada media lain. Kelebihan tersebut ialah adanya kontrol yang lebih besar pada konsumen dalam menentukan informasi apa yang ingin mereka lihat serta berapa lama mereka ingin melihat informasi tersebut [2]. Seorang pengguna internet sebagai konsumen dapat memilih situs mana yang mereka suka, situs apa yang akan mereka buka selanjutnya, serta keputusankeputusan lain yang dapat mereka tentukan pada saat mereka menggunakan internet. Hal tersebut 
lebih sulit dilakukan pada media lain, misalnya televisi atau radio.

\subsubsection{Pentarifan Iklan Online}

Ada beberapa metode yang dapat diterapkan dalam menentukan tarif sebuah iklan online. Hoffmann \& Novak [3] menyebutkan beberapa metode antara lain flat fee exposure model, cost per thousand, dan model berbasis click through. Sedangkan Sutherland \& Sylvester [4] menyebutkan dua metode yaitu metode impresi serta metode klik langsung yang pada prinsipnya mengatakan hal yang sama.

Flat fee exposure model merupakan metode pentarifan dimana pihak pengiklan diharuskan membayar dengan tarif tertentu yang bersifat tetap dalam suatu periode tertentu. Misalnya, penyedia space menentukan tarif sebesar 5 juta rupiah setiap bulan untuk iklan yang dipasang pada situs mereka. Pada tarif ini, tidak diperhitungkan besarnya traffic atau banyaknya pengunjung situs yang mengklik iklan tersebut. Metode pentarifan seperti ini adalah metode yang paling awal dipergunakan. Karena informasi banyaknya pengunjung serta traffic dari situs tersebut tidak dipertimbangkan, maka pihak pengiklan harus sangat yakin akan reputasi dari situs tersebut untuk menjamin bahwa banyak orang yang akan melihat iklan mereka.

Cost per thousand atau lazim juga disebut CPM (cost per mile) merupakan metode pentarifan dimana tarif yang berdasarkan page impression. Impression adalah jumlah sebuah iklan dilihat oleh konsumen. Jadi, pihak pengiklan akan dikenakan tarif sejumlah tertentu untuk setiap 1000 kali iklan mereka diperlihatkan kepada konsumen.

Dua metode di atas memiliki kesamaan yaitu keduanya berdasarkan pada paradigma exposuremodel dimana paradigma ini menekankan pada banyaknya pemunculan iklan tersebut di depan konsumen. Untuk mendukung metode ini, statistik yang dapat menjadi acuan bagi pihak pengiklan dapat dikeluarkan oleh penyedia space. Penyedia space iklan dapat memberikan informasi mengenai besar traffic yang secara tidak langsung akan menggambarkan tingkat kepopuleran situs mereka di mata penggunanya. Penyedia space juga dapat mengetahui besarnya kunjungan pengguna untuk setiap halaman dari situs mereka. Hal ini juga menjadi dasar penentuan tarif yang akan dibebankan kepada pihak pengiklan.

Selanjutnya, metode lain dalam menentukan tarif sebuah iklan adalah click-through. Dalam metode ini, pengiklan akan dibebani tarif yang berdasarkan pada jumlah pengunjung situs yang mengklik iklan mereka. Pada metode ini, dikenal click-through-rate (CTR) yang merupakan besaran rasio antara jumlah pengunjung situs yang mengklik iklan dibandingkan dengan jumlah seluruh pengunjung situs. Jadi jika dari 100 pengunjung situs terdapat 12 pengunjung yang mengklik sebuah iklan, iklan tersebut disebut memiliki click-through-rate sebesar $12 \%$. Dengan metode ini, pihak pengiklan dapat lebih yakin dengan performa iklan mereka dibandingkan dengan dua metode yang disebutkan sebelumnya karena respon nyata dari pengunjung sebagai konsumen mereka dapat diketahui.

\subsection{Pengukuran Efektifitas}

Pengukuran efektifitas sebuah iklan merupakan sesuatu yang sangat penting bagi sebuah iklan. Perusahaan menghabiskan banyak sekali biaya untuk membiayai iklan mereka. Oleh karena itu, perusahaan menaruh perhatian yang besar terhadap performa dari iklan mereka.

Beberapa hal menjadi alasan yang mendasari perlunya melaksanakan pengukuran efektifitas sebuah iklan. Alasan-alasan tersebut antara lain adalah untuk menghindari kesalahan yang membawa konsekuensi kerugian finansial yang besar. Misalnya jika dari pengukuran efektifitas didapat fakta bahwa iklan mereka tidak membawa pengaruh yang diharapkan, maka keputusan untuk menghentikan pembiayaan atau peredaran iklan tersebut merupakan sebuah keputusan yang masuk akal. Atau jika dari pengukuran efektifitas diketahui bahwa iklan tersebut tidak berhasil membujuk segmen konsumen yang ditargetkan, maka metode lain dapat segera dipertimbangkan.

Alasan lain adalah untuk mencari strategi alternatif dalam pemasaran yang lebih baik. Misalnya jika dari pengukuran efektifitas diketahui bahwa performa iklan mereka yang dipasang di media cetak lebih baik dari performa iklan mereka pada media elektronik, maka perusahaan dapat memfokuskan pembiayaan pada iklan di media cetak.

Pengukuran efektifitas sebuah iklan dapat dilakukan dengan dua pendekatan sesuai dengan tujuan dari iklan itu sendiri. Seperti yang telah dijelaskan di atas, tujuan pertama adalah tujuan pemasaran. Dari tujuan ini, beberapa metode bisa diterapkan antara lain peningkatan volume penjualan, peningkatan marketshare, atau peningkatan keuntungan. Metode-metode tersebut memiliki karakteristik yang sama yaitu tangible. 
Perusahaan yang memilih metode yang sesuai dengan tujuan pemasaran ini umumnya berpendapat bahwa setiap biaya yang dikeluarkan untuk sebuah iklan harus menghasilkan sesuatu yang dapat diukur.

Tujuan yang kedua, komunikasi, dapat juga menjadi basis untuk pengukuran efektifitas sebuah iklan. Pada dasarnya, metode-metode tersebut menilai seberapa baik proses komunikasi tersampaikan dengan memanfaatkan model proses respon.

Model proses respon beranggapan bahwa seseorang akan melewati tiga tahapan tersebut dalam perjalanannya memproses informasi yang didapat sampai melakukan aksi yang merupakan respon dari informasi tersebut.

\subsection{Teori Sistem Interaksi}

Dalam kaitannya dengan bidang yang ingin diteliti yaitu iklan, peneliti mengumpulkan informasi dan mempelajari teori-teori ilmu sistem interaksi yang dianggap berhubungan seperti teori data-display [5], teori penggunaan warna [6], serta teori-teori lain yang dapat mendukung penelitian.

Sistem interaksi adalah sebuah cabang ilmu yang lahir setelah komputer muncul. Pada masa awal penggunaan komputer, dibutuhkan orangorang yang sangat ahli dan memiliki kemampuan yang cukup untuk menggunakannya. Beberapa hal menjadi penyebabnya. Salah satunya adalah pada masa itu komputer merupakan sebuah alat yang sangat sulit dipergunakan dan memiliki fungsi yang sangat terbatas dan spesifik. Selain itu, harga dari sebuah komputer sangatlah mahal sehingga hanya orang atau pihak tertentu saja yang bisa memilikinya. Beberapa contohnya adalah DEC PDP-1 yang berharga \$120000, Apple Macintosh yang berharga $\$ 2500$, IBM PC-AT yang berharga $\$ 4000$ pada tahun 1984 [7]. Alasan lain adalah pada saat perancangannya, desainer komputer lebih menekankan kepada aspek komputer itu sendiri dan kurang memperhatikan aspek manusia. Hal ini dapat terjadi karena adanya asumsi bahwa membuat manusia beradaptasi terhadap sebuah sistem lebih mudah daripada sebaliknya [8]. Oleh karena itu, pada masa lalu, pengguna komputer didominasi oleh orang-orang dengan latar belakang pengetahuan komputer yang sangat tinggi seperti programmer maupun para ahli komputer lainnya.

Apa yang terjadi pada masa kini sudah berbeda. Komputer menjadi semakin murah sehingga penggunanya juga semakin meluas dan berasal dari berbagai lapisan masyarakat. Komputer semakin menjadi barang yang umum dimiliki oleh orang banyak. Lalu jika dilihat dari segi portabilitas, komputer juga mengalami kemajuan yang luar biasa dari komputer seukuran ruangan hingga notebook yang sekarang ini lazim dijumpai. Kegunaan komputer pada masa kini sangatlah beragam, mulai dari pekerjaan kantor seperti mengetik sampai pekerjaan yang sangat kompleks seperti mengatur lalu lintas penerbangan pada sebuah menara kendali di bandara.

Perubahan yang terjadi tersebut membuat pada desainer komputer menemukan tantangan baru yaitu mencari cara bagaimana membuat komputer yang dapat membuat penggunanya merasa nyaman dan familiar. Hal ini berarti bahwa aspek hubungan atau interaksi antara manusia sebagai pengguna komputer harus diperhatikan. Proses interaksi tersebut haruslah berjalan selancar dan semudah mungkin. Salah satu terminologi yang lazim dibahas dalam kaitannya dengan interaksi tersebut adalah user-interface atau antarmuka.

Telah banyak pihak yang melakukan upayaupaya untuk membuat komputer menjadi lebih nyaman dipakai manusia. Peneliti-peneliti dari bidang akademis berkontribusi dengan melakukan serangkaian penelitian yang berkaitan dengan aspek psikologi terhadap penggunaan komputer oleh manusia. Akhirnya, pada tahun 1980-an mulai dikenal istilah Human Computer Interaction (HCI) yang kemudian didefinisikan sebagai disiplin ilmu yang mempelajari tentang desain, evaluasi dan penerapan sistem antarmuka komputer untuk manusia serta fenomena-fenomena besar yang terjadi di sekitarnya.

Sebuah komputer yang memperhatikan aspek manusia pada desainnya akan memperhatikan usability. Pada masa lalu, para desainer masih kurang memberikan perhatian yang cukup kepada usability. Oleh karena itu, pada masa kini dimana pengunaan komputer sudah sangat luas, desainer maupun pihak lain yang berkecimpung dalam dunia komputer harus memastikan bahwa sistem mereka memiliki usability yang baik. Beberapa hal yang harus diperhatikan sesuai yang disebutkan oleh Rubin adalah kegunaan, kemudahan penggunaan, kemudahan untuk dipelajari, dan kesukaan pengguna pada sistem tersebut.

Penerapan dari sebuah desain yang memperhatikan aspek manusia antara lain adalah pada cara menampilkan menu, cara mengisi form, cara menampilkan pesan error dan cara menampilkan data. Cara menampilkan sebuah data pada layar komputer merupakan salah satu hal yang 
termasuk bidang ilmu sistem interaksi karena berhubungan dengan manusia sebagai pihak yang akan melihatnya. Tampilan menjadi hal yang sangat berpengaruh terhadap desain interactive system yang sukses [5]. Panduan yang diciptakan oleh Smith \& Mosier [2] dapat menjadi acuan dalam menampilkan suatu data.

Berdasarkan panduan tersebut, sebuah sistem harus menampilkan data yang diperlukan pengguna. Pada kaitannya dengan iklan ini, sebuah iklan harus memberikan ilustrasi produk yang diiklankan karena hal tersebut merupakan data yang diperlukan oleh konsumen sebagai pengguna komputer untuk dapat membuat keputusan terhadap iklan tersebut. Selain itu, disebutkan juga bahwa untuk menarik perhatian pengguna, strategi pemilihan warna juga dapat menjadi pilihan. Hal ini sangat berhubungan dengan iklan karena salah satu tujuan iklan adalah menarik perhatian pemirsanya.

Sebuah desain sistem komputer tidak akan dapat memuaskan kebutuhan semua pihak, oleh karena itu, desain harus dikhususkan dengan karakter pengguna dan situasi dimana desain tersebut digunakan. Penerapan hal ini pada bidang iklan adalah keperluan untuk menciptakan iklan yang sesuai dengan target konsumennya. Sebuah iklan harus mampu mengetahui karakteristik konsumen mereka untuk dapat memformulasikan iklan yang efektif. Karakteristik ini misalnya usia, jenis kelamin, kelas sosial, dan pekerjaan. Sebuah contoh iklan yang memperhatikan karakteristik ini misalnya iklan yang menggunakan ukuran font lebih besar untuk mengakomodasi pengguna yang berusia lebih tua.

Pengukuran efektifitas sebuah iklan merupakan sesuatu yang sangat penting bagi sebuah iklan. Perusahaan menghabiskan banyak sekali biaya untuk membiayai iklan mereka. Oleh karena itu, perusahaan menaruh perhatian yang besar terhadap performa dari iklan mereka.

\subsection{Hasil Wawancara}

Wawancara dilakukan terhadap tiga narasumber yang masing-masing memiliki pengalaman pada bidang iklan online. Jabatan para narasumber adalah konsultan online marketing di detikcom, marketing manager serta IT manager di Grey Group. Kepada mereka kemudian ditanyakan sejumlah pertanyaan yang terkait dengan iklan online.

Dari wawancara yang dilakukan pada 26 Maret 2008 dan 8 April 2008 tersebut, didapatlah informasi-informasi yang berguna yang meliputi desain iklan yang efektif serta metode untuk mengukur efektifitas sebuah iklan online. Sebuah iklan yang menarik perhatian disebut sebagai iklan yang cenderung lebih efektif dibandingkan dengan iklan yang sebaliknya. Menarik perhatian dapat diartikan dengan komposisi warna yang jelas dan memiliki tingkat kontras yang baik namun masih tetap memperhatikan keindahannya dan tidak sekadar menarik perhatian. Selain itu, penentuan lokasi iklan juga menentukan efektifitas sebuah iklan online. Contoh yang dikemukakan adalah iklan produk kesehatan pada situs yang bertema gaya hidup sehat akan lebih efektif daripada iklan kendaraan pada situs yang sama.

Jenis iklan juga merupakan hal yang disebut berpengaruh terhadap efektifitas. Sebuah iklan bertipe pop-up dapat merusak suasana hati pengguna dan berpotensi menimbulkan dampak buruk bagi performa iklan tersebut.

Gaya bahasa juga merupakan hal yang harus diperhatikan. Gaya bahasa disebut tergantung dari usia pengguna komputer sebagai target konsumen. Sebuah iklan yang menerapkan gaya bahasa nonformal disebutkan lebih efektif untuk target konsumen yang lebih muda.

Posisi sebuah iklan pada layar juga disebut berpengaruh terhadap efektifitas sebuah iklan. Hal ini dijelaskan dengan perbedaan tarif yang diterapkan oleh penyedia space iklan online.

Pengukuran efektifitas sebuah iklan online pada umumnya menggunakan jumlah klik. Pengukuran efektifitas sebuah iklan merupakan sesuatu yang sangat penting bagi sebuah iklan. Perusahaan menghabiskan banyak sekali biaya untuk membiayai iklan mereka. Oleh karena itu, perusahaan menaruh perhatian yang besar terhadap performa dari iklan mereka.

\subsection{Teknik Statistik}

Teknik statistik yang akan dilakukan adalah Goodness-of-Fit Test yang merupakan salah satu varian Chi-Square Test. Tes ini berfungsi untuk menguji hipotesis dengan dua atau lebih kemungkinan ketegori. Eksperimen yang dimaksud ialah multinomial experiment. Ada beberapa komponen yang perlu diperhatikan pada Goodnessof-Fit Test ini. Hal hal tersebut adalah sebagai berikut.

\section{Observed Frequency $(O)$}

Observed Frequency adalah frekuensi yang didapat dari eksperimen. 


\section{Probability $(\boldsymbol{p})$}

Probability adalah kemungkinan dari kemunculan sebuah elemen jika null hypothesis benar.

3. Expected Frequency $(E)$

Expected Frequency adalah frekuensi yang diharapkan akan didapat jika null hypothesis benar. $E$ didapat dengan mengalikan sample size ( $n$ ) dengan $p$. $E=n p$

\section{Degree of Freedom $(d f)$}

Degree of freedom didapat dari jumlah kategori $k$ dikurangi 1.

$$
d f=k-1
$$

\subsection{Hipotesis Penelitian}

Dari hasil studi literatur serta wawancara, diketahui faktor-faktor yang diasumsikan berpengaruh terhadap efektifitas sebuah iklan online. Ketujuh faktor ini kemudian akan diuji dalam sebuah eksperimen untuk mengetahui kebenarannya. Faktor-faktor beserta hipotesisnya adalah sebagai berikut.

Tabel 1. Hipotesis Penelitian

\begin{tabular}{|c|c|}
\hline Faktor & Hipotesis \\
\hline \multirow[t]{2}{*}{$\begin{array}{l}\text { Keberadaan } \\
\text { Ilustrasi }\end{array}$} & $\begin{array}{l}H_{0} \text { : Keberadaan ilustrasi tidak berpengaruh } \\
\text { terhadap efektifitas sebuah iklan online. }\end{array}$ \\
\hline & $\begin{array}{l}H_{1}: \text { Keberadaan ilustrasi berpengaruh } \\
\text { terhadap efektifitas sebuah iklan online. }\end{array}$ \\
\hline \multirow[t]{2}{*}{$\begin{array}{l}\text { Komposisi } \\
\text { Warna }\end{array}$} & $\begin{array}{l}H_{0} \text { : Komposisi warna tidak berpengaruh } \\
\text { terhadap efektifitas sebuah iklan online. }\end{array}$ \\
\hline & $\begin{array}{l}H_{1}: \text { Komposisi warna berpengaruh } \\
\text { terhadap efektifitas sebuah iklan online. }\end{array}$ \\
\hline \multirow[t]{2}{*}{ Gaya Bahasa } & $\begin{array}{l}H_{0}: \text { Gaya bahasa tidak berpengaruh } \\
\text { terhadap efektifitas sebuah iklan online. }\end{array}$ \\
\hline & $\begin{array}{l}H_{1} \text { : Gaya bahasa berpengaruh terhadap } \\
\text { efektifitas sebuah iklan online. }\end{array}$ \\
\hline \multirow[t]{2}{*}{ Posisi } & $\begin{array}{l}H_{0}: \text { Posisi tidak berpengaruh terhadap } \\
\text { efektifitas sebuah iklan online. }\end{array}$ \\
\hline & $\begin{array}{l}H_{1} \text { : Posisi berpengaruh terhadap efektifitas } \\
\text { sebuah iklan online. }\end{array}$ \\
\hline \multirow[t]{2}{*}{ Ukuran Font } & $\begin{array}{l}H_{0}: \text { Ukuran font tidak berpengaruh } \\
\text { terhadap efektifitas sebuah iklan online. }\end{array}$ \\
\hline & $\begin{array}{l}H_{1} \text { : Ukuran font berpengaruh terhadap } \\
\text { efektifitas sebuah iklan online. }\end{array}$ \\
\hline \multirow[t]{2}{*}{ Lokasi } & $\begin{array}{l}H_{0} \text { : Lokasi tidak berpengaruh terhadap } \\
\text { efektifitas sebuah iklan online. }\end{array}$ \\
\hline & $\begin{array}{l}H_{1}: \text { Lokasi berpengaruh terhadap } \\
\text { efektifitas sebuah iklan online. }\end{array}$ \\
\hline \multirow[t]{2}{*}{ Jenis } & $\begin{array}{l}H_{0}: \text { Jenis tidak berpengaruh terhadap } \\
\text { efektifitas sebuah iklan online. }\end{array}$ \\
\hline & $\begin{array}{l}H_{1} \text { : Jenis berpengaruh terhadap efektifitas } \\
\text { sebuah iklan online. }\end{array}$ \\
\hline
\end{tabular}

\section{Metode Penelitian}

Penelitian ini dilakukan dengan metode yang terdiri dari beberapa tahap. Tahap-tahap tersebut adalah sebagai berikut.

\subsection{Studi Literatur}

Tahap ini dilakukan penulis untuk mempelajari seluk beluk iklan pada umumnya serta iklan online pada khususnya serta metode untuk mengukur efektifitas sebuah iklan. Tahap ini penting untuk membangun pengertian yang benar dan memadai untuk melakukan penelitian ini. Selain itu, penulis juga mempelajari teori-teori yang terdapat dalam ilmu sistem interaksi untuk membangun aspek dasar yang akan diujikan kepada iklan dalam eksperimen.

\subsection{Wawancara}

Selanjutnya penulis melakukan wawancara terhadap narasumber yang memiliki kompetensi memadai pada bidang iklan online. Wawancara ini dilakukan untuk mendapatkan informasi yang juga mendasari penelitian ini. Informasi yang didapat dari wawancara ini selanjutnya akan dibandingkan dengan informasi dari studi literatur untuk membuat rancangan eksperimen dalam rangka membuktikan kebenarannya.

\subsection{Eksperimen}

Pada tahap ini penulis mendesain sebuah eksperimen yang bertujuan untuk mengetahui faktor-faktor apa saja yang berpengaruh terhadap efektifitas sebuah iklan sesuai basis yang telah didapat dari studi literatur dan wawancara. Eksperimen yang dilakukan bersifat online dan dihost pada IDwebhost dengan url http://ilhamajipratomo.web.id/TA.

\subsection{Analisis Hasil Eksperimen}

Hasil eksperimen kemudian akan diolah untuk dianalisis melalui sudut pandang demografis yang dapat dilakukan seperti usia, gender, dan lain lain.

Populasi dari penelitian ini adalah civitas akademika Universitas Indonesia yang pernah menggunakan internet. Sampel dari penelitian ini akan diambil dari populasi sejumlah minimal 100 dengan varian metode random-sampling yaitu stratified random sampling berdasarkan profesi yang terbagi atas mahasiswa/mahasiswi, staf akademik dan staf non-akademik. Alasan dari penentuan jumlah sampel adalah syarat metode Goodness-of-Fit Test yang mengharuskan setiap kategori (dalam hal ini setiap kelompok iklan yang 
akan diuji berdasarkan faktornya) sebaiknya memiliki expected value miminal 5. Sedangkan metode random-sampling dipilih karena kemampuannya dalam memberikan generalisasi yang cukup terhadap populasi.

Penelitian ini akan menggunakan kuisioner yang berisi pertanyaan-pertanyaan yang menanyakan hal sebagai berikut:
a) Jenis Kelamin
b) Usia
c) Status Pernikahan
d) Suku Bangsa
e) Profesi
f) Pengeluaran Per Bulan
g) Frekuensi Penggunaan Internet Per Hari
h) Pengalaman Mencari Informasi Produk/Jasa via Internet
i) Pengalaman Menjumpai Iklan Online
j) Pengalaman Membeli Produk/Jasa via Internet

Data untuk penelitian ini akan berasal dari kuisioner online yang diisi oleh sejumlah responden. Pada kuisioner tersebut, responden akan diminta untuk mengisi data dirinya yang bersifat demografis. Setelah itu, responden akan diperlihatkan tujuh halaman berisi iklan yang disesuaikan berdasarkan variabel yang telah ditentukan. Lalu, responden akan diminta untuk memilih salah satu iklan yang mereka sukai pada setiap halaman.

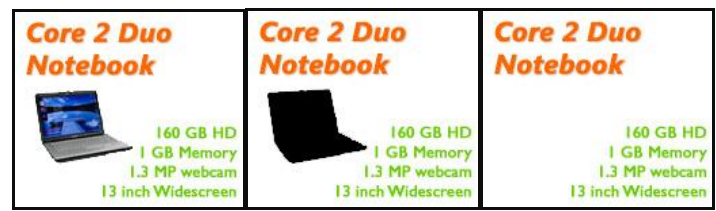

Gambar 1. Iklan Pada Kelompok Ilusrasi

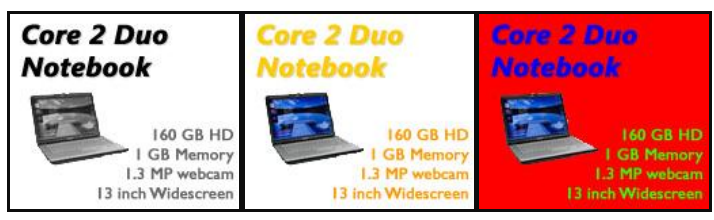

Gambar 2. Iklan Pada Kelompok Warna

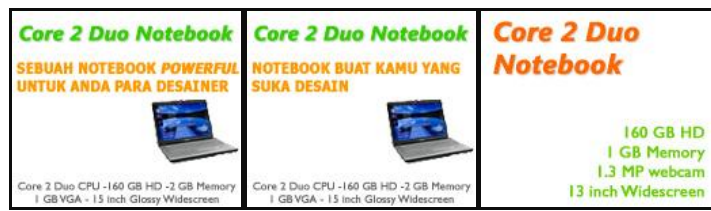

Gambar 3. Iklan Pada Kelompok Gaya Bahasa

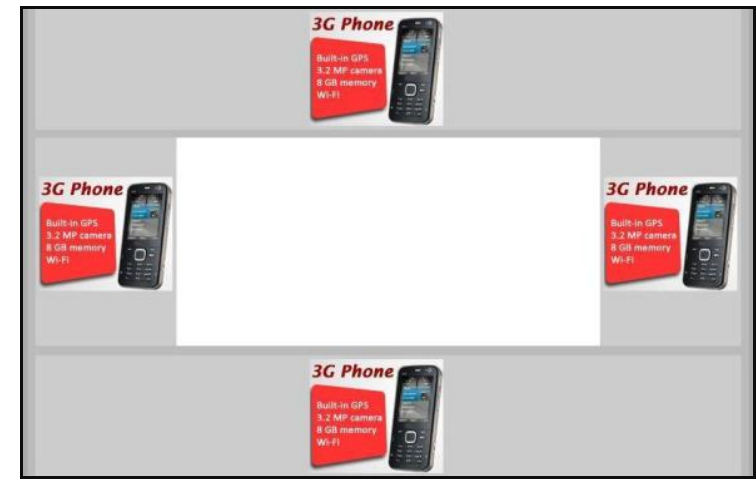

Gambar 4. Iklan Pada Kelompok Posisi

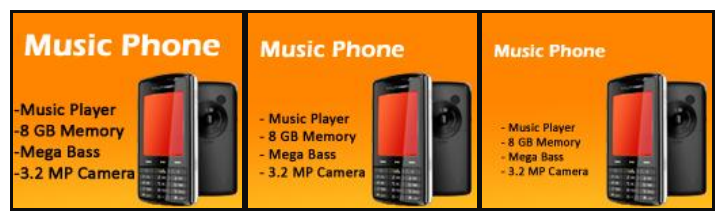

Gambar 5. Iklan Pada Kelompok Ukuran Font

The Steakhouse - Four Seasons Hotel

The Steakhouse yang berada di lantai dua Four Seasons Hotel ini telah lama menjadi favorit di kalangan penikmat steik kelas premium. Sebagai restoran yang secara spesifik menjadikan steik sebagai andalannya, tampak sekali keseriusan sekaligus kematangan pengalaman dalam penyajian steik. The Steakhouse juga menawarkan berbagai jenis side dish lain untuk menemani line up steik-nya, seperti steamed vegetables, buttered mashed potatoes, hingga crispy onion rings.

sumber: rileks.com dengan perubahan seperlunya

Gambar 6. Teks paragraph Pada Halaman Uji Kelompok Lokasi

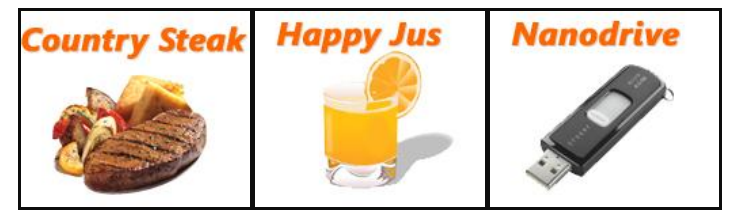

Gambar 7. Iklan Pada Kelompok Lokasi

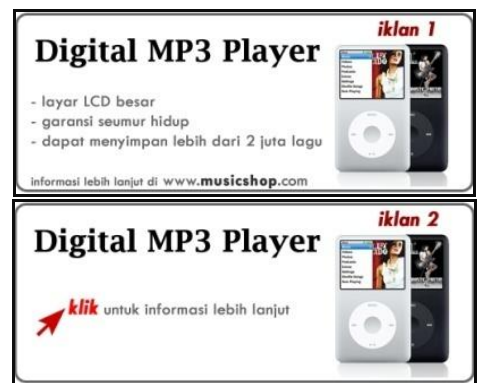

Gambar 8. Iklan Pada Kelompok Jenis 


\subsection{Teknik Pengolahan dan Analisis Data}

Data yang didapat dari kuisioner akan diolah dengan teknik inferential statistic dan descriptive statistic. Pertama, data jumlah klik setiap iklan untuk setiap variabel akan disusun menurut iklan. Lalu, data tersebut akan diuji untuk setiap variabel dengan teknik inferential statistic yaitu dengan Goodness-of-Fit Test yang merupakan varian dari Chi-Square Test.

Dari uji tersebut, akan di dapat nilai $x^{2}$ yang akan dibandingkan dengan nilai kritis Chi-Square pada tabel statistik. Jika nilai $x^{2}$ tersebut lebih besar dari nilai Chi-Square, maka akan diambil kesimpulan bahwa $\mathrm{H}_{0}$ ditolak yang berimplikasi bahwa variabel yang sedang diuji berpengaruh pada efektifitas iklan.

Selanjutnya, dari hasil yang didapat dari Goodness-of-Fit Test akan dianalisis dengan melihat karakter demografi dari responden untuk diteliti apakah yang melatarbelakangi pengaruh suatu faktor dengan menggunakan descriptive statistic.

Pada penelitian ini juga telah dilakukan pilot test sebelumnya untuk menentukan apakah eksperimen layak dilakukan. Dan setelah dilakukan pilot test tersebut, maka eksperimen dinyatakan layak dilakukan dengan melihat hasil pilot test.

\section{Analisis Data dan Pembahasan}

Proses pencarian responden untuk penelitian dilakukan dari tanggal 16 Juni 2008 sampai tanggal 27 Juni 2008. Dari proses tersebut, peneliti mendapatkan 106 responden. Namun, karena 3 di antaranya tidak dapat menyelesaikan eksperimen sehingga mengakibatkan data yang diberikan tidak lengkap, maka penulis mencoret tiga responden tersebut dari daftar responden yang berimplikasi pada jumlah responden yang akhirnya sebesar 103 reponden. Dari eksperimen, didapatlah data deskriptif sebagai berikut.

Dari 103 orang yang berpatrisipasi dalam eksperimen, mayoritas berasal dari Fakultas Ilmu Komputer yaitu sebanyak 15 orang atau $15 \%$ dari total sampel. Sedangkan dari jenis kelamin, mayoritas responden adalah pria dengan presentase $51 \%$.

Dari segi usia, mayoritas responden berusia antara 18 sampai 22 tahun. Hal ini disebabkan oleh mayoritas responden yang merupakan mahasiswa sebanyak $89 \%$. Dari status pernikahan, mayoritas responden belum menikah. Sedangkan dari segi suku bangsa, mayoritas responden merupakan suku
Jawa. Lalu untuk segi pengeluaran, didominasi oleh responden yang memiliki pengeluaran antara 500.000 rupiah sampai 1.000 .000 rupiah.

Dari 103 responden tersebut, ditemukan juga bahwa mayoritas menggunakan internet selama satu sampai tiga jam per harinya dan mereka umumnya pernah melihat iklan online dan pernah mencari informasi produk/jasa namun kebanyakan dari mereka belum pernah membeli produk/jasa via internet.

\subsection{Analisis Data}

Dari data yang dihasilkan melalui kuisioner, peneliti akan melakukan uji statistik Goodness-ofFit Test. Untuk penelitian ini, peneliti menggunakan nilai alpha sebesar 0,001. Penggunaan nilai alpha sebesar mengakibatkan kemungkinan null hypothesis ditolak sebesar 0,1 persen untuk meningkatkan kredibilitas analisis dari penelitian ini.

Langkah-langkah dalam melakukan Goodnessof-Fit Test pada penelitian ini adalah sebagai berikut:

1. Menyatakan null hypothesis serta alternative hypothesis.

2. Memilih distribusi yang akan dipergunakan.

3. Menentukan rejection dan nonrejection region.

4. Mengkalkulasi nilai dari uji statistik.

5. Membuat keputusan.

Selanjutnya akan dilakukan Goodness-of-Fit Test pada setiap kelompok yang merupakan variabel penelitian.

\subsubsection{Analisis Terhadap Keberadaan Ilustrasi}

Tabel 2. Analisi Terhadap Ilustrasi

\begin{tabular}{|c|c|c|c|c|c|c|}
\hline $\begin{array}{c}\text { Kategori } \\
\text { (Iklan) }\end{array}$ & $\begin{array}{c}\text { Observed } \\
\text { Frequency } \\
O\end{array}$ & $p$ & $\begin{array}{c}\text { Expected } \\
\text { Frequency } \\
\boldsymbol{E}=n p\end{array}$ & $(O-E)$ & $(O-E) 2$ & $\frac{(O-E) 2}{E}$ \\
\hline Iklan 1 & 95 & 0,33 & $\begin{array}{r}103(0,33) \\
=34,33\end{array}$ & 60,67 & 3680,44 & 107,19 \\
\hline Iklan 2 & 6 & 0,33 & $\begin{array}{r}103(0,33) \\
=34,33\end{array}$ & 28,33 & 802,78 & 23,38 \\
\hline Iklan 3 & 2 & 0,33 & $\begin{array}{r}103(0,33) \\
=34,33\end{array}$ & $\begin{array}{r}- \\
32,33\end{array}$ & 1045,44 & 30,45 \\
\hline & $n=103$ & & & & & $\begin{array}{l}\text { Total }= \\
161,03\end{array}$ \\
\hline
\end{tabular}

Setelah didapat nilai $x^{2}$ dari tes statistik tersebut, maka nilai tersebut lalu dibandingkan dengan nilai kritis $x^{2}$ yaitu 13,81. Dapat dilihat bahwa nilai dari tes statistik melebihi nilai kritis $x^{2}$ yang mengakibatkan nilai tersebut berada pada daerah 
penolakan.

Dari hasil tersebut, dapat disimpulkan bahwa null hypothesis ditolak atau dengan kata lain, proporsi dari responden yang memilih iklan pada kelompok ilustrasi tidak seragam untuk setiap kategori. Hal ini menunjukkan bahwa terdapat indikasi kuat bahwa ada keterkaitan antara penggunaan ilustrasi pada sebuah iklan dan jumlah orang yang mengklik iklan tersebut. Dengan kata lain, dapat dinyatakan bahwa ilustrasi berpengaruh terhadap efektifitas sebuah iklan online.

\subsubsection{Analisis Terhadap Warna}

Tabel 3. Analisis Terhadap Warna

\begin{tabular}{|c|c|c|c|c|c|c|}
\hline $\begin{array}{c}\text { Kategori } \\
\text { (Iklan) }\end{array}$ & $\begin{array}{c}\text { Observed } \\
\text { Frequency } \\
\boldsymbol{O}\end{array}$ & $p$ & $\begin{array}{c}\text { Expected } \\
\text { Frequency } \\
\boldsymbol{E}=n p\end{array}$ & $(O-E)$ & $(O-E) 2$ & $\frac{(O-E) 2}{E}$ \\
\hline Iklan 1 & 12 & 0,33 & $\begin{array}{r}103(0,33)= \\
34,33\end{array}$ & $-22,33$ & 498,78 & 14,53 \\
\hline Iklan 2 & 62 & 0,33 & $\begin{array}{r}103(0,33)= \\
34,33\end{array}$ & 27,67 & 765,44 & 22,29 \\
\hline Iklan 3 & 29 & 0,33 & $\begin{array}{r}103(0,33)= \\
34,33\end{array}$ & $-5,33$ & 28,44 & 0,83 \\
\hline & $n=103$ & & & & & $\begin{array}{r}\text { Total }= \\
37,65\end{array}$ \\
\hline
\end{tabular}

Setelah didapat nilai $x^{2}$ dari tes statistik tersebut, maka nilai tersebut lalu dibandingkan dengan nilai kritis $x^{2}$ yaitu 13, 81. Dapat dilihat bahwa nilai dari tes statistik melebihi nilai kritis $x^{2}$ yang mengakibatkan nilai tersebut berada pada daerah penolakan.

Dari hasil tersebut, dapat disimpulkan bahwa null hypothesis ditolak atau dengan kata lain, proporsi dari responden yang memilih iklan pada kelompok warna tidak seragam untuk setiap kategori. Hal ini menunjukkan bahwa terdapat indikasi kuat bahwa ada keterkaitan antara penggunaan warna pada sebuah iklan dan jumlah orang yang mengklik iklan tersebut. Dengan kata lain, dapat dinyatakan bahwa warna berpengaruh terhadap efektifitas sebuah iklan online.

\subsubsection{Analisis Terhadap Gaya Bahasa}

Setelah didapat nilai $x^{2}$ dari tes statistik tersebut, maka nilai tersebut lalu dibandingkan dengan nilai kritis $x^{2}$ yaitu 13,81 . Dapat dilihat bahwa nilai dari tes statistik melebihi nilai kritis $x^{2}$ yang mengakibatkan nilai tersebut berada pada daerah penolakan.

Dari hasil tersebut, dapat disimpulkan bahwa null hypothesis ditolak atau dengan kata lain, proporsi dari responden yang memilih iklan pada kelompok gaya bahasa tidak seragam untuk setiap kategori. Hal ini menunjukkan bahwa terdapat indikasi kuat bahwa ada keterkaitan antara penggunaan gaya bahasa pada sebuah iklan dan jumlah orang yang mengklik iklan tersebut. Dengan kata lain, dapat dinyatakan bahwa gaya bahasa berpengaruh terhadap efektifitas sebuah iklan online.

Tabel 4. Analisis Terhadap Gaya Bahasa

\begin{tabular}{|c|c|c|c|c|c|c|}
\hline $\begin{array}{c}\text { Kategori } \\
\text { (Iklan) }\end{array}$ & $\begin{array}{c}\text { Observed } \\
\text { Frequency } \\
\boldsymbol{O}\end{array}$ & $p$ & $\begin{array}{c}\text { Expected } \\
\text { Frequency } \\
\boldsymbol{E}=n p\end{array}$ & $(O-E)$ & $(O-E) 2$ & $\frac{(O-E) 2}{E}$ \\
\hline Iklan 1 & 51 & 0,33 & $\begin{array}{r}103(0,33)= \\
34,33\end{array}$ & 16,67 & 277,78 & 8,09 \\
\hline Iklan 2 & 34 & 0,33 & $\begin{array}{r}103(0,33)= \\
34,33\end{array}$ & $-0,33$ & 0,11 & 0,003 \\
\hline Iklan 3 & 18 & 0,33 & $\begin{array}{r}103(0,33)= \\
34,33\end{array}$ & $-16,33$ & 266,78 & 7,77 \\
\hline & $n=103$ & & & & & $\begin{array}{r}\text { Total }= \\
15,86\end{array}$ \\
\hline
\end{tabular}

\subsubsection{Analisis Terhadap Posisi}

Tabel 5. Analisis Terhadap Posisi

\begin{tabular}{|c|c|c|c|c|c|c|}
\hline $\begin{array}{c}\text { Kategori } \\
\text { (Iklan) }\end{array}$ & $\begin{array}{c}\text { Observed } \\
\text { Frequency } \\
\boldsymbol{O}\end{array}$ & $p$ & $\begin{array}{c}\text { Expected } \\
\text { Frequency } \\
\boldsymbol{E}=n p\end{array}$ & $(O-E)$ & $(O-E) 2$ & $\frac{(O-E) 2}{E}$ \\
\hline Iklan 1 & 43 & 0,25 & $\begin{array}{r}103(0,25)= \\
25,75\end{array}$ & 17,25 & 297,56 & 11,56 \\
\hline Iklan 2 & 11 & 0,25 & $\begin{array}{r}103(0,25)= \\
25,75\end{array}$ & $-14,75$ & 217,56 & 8,45 \\
\hline Iklan 3 & 35 & 0,25 & $\begin{array}{r}103(0,25)= \\
25,75\end{array}$ & 9,25 & 85,56 & $\overline{3,32}$ \\
\hline & 14 & 0,25 & $\begin{array}{r}103(0,25)= \\
25,75\end{array}$ & $-11,75$ & 138,06 & 5,36 \\
\hline & $n=103$ & & & & & $\begin{array}{r}\text { Total }= \\
28,69\end{array}$ \\
\hline
\end{tabular}

Setelah didapat nilai $x^{2}$ dari tes statistik tersebut, maka nilai tersebut lalu dibandingkan dengan nilai kritis $x^{2}$ yaitu 16,27. Dapat dilihat bahwa nilai dari tes statistik melebihi nilai kritis $x^{2}$ yang mengakibatkan nilai tersebut berada pada daerah penolakan.

Dari hasil tersebut, dapat disimpulkan bahwa null hypothesis ditolak atau dengan kata lain, proporsi dari responden yang memilih iklan pada kelompok posisi tidak seragam untuk setiap kategori. Hal ini menunjukkan bahwa terdapat indikasi kuat bahwa ada keterkaitan antara posisi pada sebuah iklan dan jumlah orang yang mengklik iklan tersebut. Dengan kata lain, dapat dinyatakan bahwa posisi berpengaruh terhadap efektifitas sebuah iklan online. 


\subsubsection{Analisis Terhadap Ukuran Font}

Setelah didapat nilai $x^{2}$ dari tes statistik tersebut, maka nilai tersebut lalu dibandingkan dengan nilai kritis $x^{2}$ yaitu 13, 81. Dapat dilihat bahwa nilai dari tes statistik melebihi nilai kritis $x^{2}$ yang mengakibatkan nilai tersebut berada pada daerah penolakan.

Tabel 6. Analisis Terhadap Ukuran Font

\begin{tabular}{|c|r|r|r|r|r|r|}
\hline $\begin{array}{c}\text { Kategori } \\
\text { (Iklan) }\end{array}$ & $\begin{array}{c}\text { Observed } \\
\text { Frequency } \\
\boldsymbol{O}\end{array}$ & $\boldsymbol{p}$ & $\begin{array}{r}\text { Expected } \\
\text { Frequency } \\
\boldsymbol{E}=n p\end{array}$ & $(O-E)$ & $(O-E) 2$ & $\frac{(O-E) 2}{E}$ \\
\hline Iklan 1 & 80 & 0,33 & $\begin{array}{r}103(0,33)= \\
34,33\end{array}$ & 45,67 & 2085,44 & 60,74 \\
\hline Iklan 2 & 18 & 0,33 & $\begin{array}{r}103(0,33)= \\
34,33\end{array}$ & $-16,33$ & 266,78 & 7,77 \\
\hline Iklan 3 & 5 & 0,33 & $\begin{array}{r}103(0,33)= \\
34,33\end{array}$ & $-29,33$ & 860,44 & 25,06 \\
\hline & $n=103$ & & & & & $\begin{array}{r}\text { Total = } \\
93,57\end{array}$ \\
\hline
\end{tabular}

Dari hasil tersebut, dapat disimpulkan bahwa null hypothesis ditolak atau dengan kata lain, proporsi dari responden yang memilih iklan pada kelompok ukuran font tidak seragam untuk setiap kategori. Hal ini menunjukkan bahwa terdapat indikasi kuat bahwa ada keterkaitan antara ukuran font pada sebuah iklan dan jumlah orang yang mengklik iklan tersebut. Dengan kata lain, dapat dinyatakan bahwa ukuran font berpengaruh terhadap efektifitas sebuah iklan online.

\subsubsection{Analisis Terhadap Lokasi}

Setelah didapat nilai $x^{2}$ dari tes statistik tersebut, maka nilai tersebut lalu dibandingkan dengan nilai kritis $x^{2}$ yaitu 13, 81. Dapat dilihat bahwa nilai dari tes statistik melebihi nilai kritis $x^{2}$ yang mengakibatkan nilai tersebut berada pada daerah penolakan.

Tabel 7. Analisis Terhadap Lokasi

\begin{tabular}{|c|r|r|r|r|r|r|}
\hline $\begin{array}{c}\text { Kategori } \\
\text { (Iklan) }\end{array}$ & $\begin{array}{c}\text { Observed } \\
\text { Frequency } \\
\boldsymbol{O}\end{array}$ & $\boldsymbol{p}$ & $\begin{array}{r}\text { Expected } \\
\text { Frequency } \\
\boldsymbol{E}=n p\end{array}$ & $(O-E)$ & $(O-E) 2$ & $\frac{(O-E) 2}{E}$ \\
\hline Iklan 1 & 87 & 0,33 & $\begin{array}{r}103(0,33)= \\
34,33\end{array}$ & 52,67 & 2773,78 & 80,79 \\
\hline Iklan 2 & 11 & 0,33 & $\begin{array}{r}103(0,33)= \\
34,33\end{array}$ & $-23,33$ & 544,44 & 15,86 \\
\hline Iklan 3 & 5 & 0,33 & $\begin{array}{r}103(0,33)= \\
34,33\end{array}$ & $-29,33$ & 860,44 & 25,06 \\
\hline$n=103$ & & & & & $\begin{array}{c}\text { Total }= \\
121,71\end{array}$ \\
\hline
\end{tabular}

Dari hasil tersebut, dapat disimpulkan bahwa null hypothesis ditolak atau dengan kata lain, proporsi dari responden yang memilih iklan pada kelompok lokasi tidak seragam untuk setiap kategori. Hal ini menunjukkan bahwa terdapat indikasi kuat bahwa ada keterkaitan antara lokasi pada sebuah iklan dan jumlah orang yang mengklik iklan tersebut. Dengan kata lain, dapat dinyatakan bahwa ukuran lokasi berpengaruh terhadap efektifitas sebuah iklan online.

\subsubsection{Analisis Terhadap Jenis}

Tabel 8. Analisis Terhadap Jenis

\begin{tabular}{|c|c|c|c|c|c|c|}
\hline $\begin{array}{c}\text { Kategori } \\
\text { (Iklan) }\end{array}$ & $\begin{array}{c}\text { Observed } \\
\text { Frequency } \\
\boldsymbol{O}\end{array}$ & $\boldsymbol{p}$ & $\begin{array}{c}\text { Expected } \\
\text { Frequency } \\
\boldsymbol{E}=n p\end{array}$ & $(O-E)$ & $(O-E) 2$ & $\frac{(O-E) 2}{E}$ \\
\hline Iklan 1 & 82 & 0,50 & $\begin{array}{r}103(0,50)= \\
51,50\end{array}$ & 30,5 & 930,25 & 18,06 \\
\hline Iklan 2 & 21 & 0,50 & $\begin{array}{r}103(0,50)= \\
51,50\end{array}$ & $-30,5$ & 930,25 & 18,06 \\
\hline & & & & & $\begin{array}{r}\text { Total } \\
36,13\end{array}$ \\
\hline
\end{tabular}

Setelah didapat nilai $x^{2}$ dari tes statistik tersebut, maka nilai tersebut lalu dibandingkan dengan nilai kritis $x^{2}$ yaitu 10,83 . Dapat dilihat bahwa nilai dari tes statistik melebihi nilai kritis $x^{2}$ yang mengakibatkan nilai tersebut berada pada daerah penolakan.

Dari hasil tersebut, dapat disimpulkan bahwa null hypothesis ditolak atau dengan kata lain, proporsi dari responden yang memilih iklan pada kelompok jenis tidak seragam untuk setiap kategori. Hal ini menunjukkan bahwa terdapat indikasi kuat bahwa ada keterkaitan antara jenis sebuah iklan dan jumlah orang yang mengklik iklan tersebut. Dengan kata lain, dapat dinyatakan bahwa jenis berpengaruh terhadap efektifitas sebuah iklan online.

\section{Penutup}

\subsection{Kesimpulan}

Dari penelitian ini, dapat diambil kesimpulan yang berhubungan dengan tujuan penelitian yang telah disebutkan pada awal laporan ini. Pada awal laporan disebutkan bahwa penelitian ini bertujuan untuk mengetahui faktor-faktor apa saja yang mempengaruhi efektifitas sebuah iklan online.

Tes statistik Goodness-of-Fit yang dilakukan pada beberapa faktor terhadap hubungannya dengan iklan online menunjukkan bahwa ketujuh faktor yang diujikan terbukti mempengaruhi jumlah klik pada iklan. Seluruh null hypothesis $\mathrm{H}_{0}$ yang menjadi perangkat penelitian terbukti ditolak. Hal ini berimplikasi kepada kesimpulan bahwa ketujuh faktor tersebut mempengaruhi efektifitas iklan online sesuai dengan definisi efektifitas pada 
eksperimen sebagai banyaknya jumlah klik.

Jika melihat dari selisih nilai antara nilai $x^{2}$ yang didapat dari uji statistik dengan nilai kritis $x^{2}$ pada tabel distribusi Chi-Square yang dipakai, dapat dilihat bahwa ketujuh faktor tersebut memiliki selisih yang berbeda-beda. Dari selisih tersebut, dapat dilihat bahwa keberadaan ilustrasi dan lokasi merupakan dua faktor dengan selisih terbesar. Hal ini dapat menjadi perhatian bagi pihak-pihak yang ingin merancang sebuah iklan.

Tabel 9. Kesimpulan Hasil Penelitian

\begin{tabular}{|c|c|c|c|}
\hline Faktor & Hasil & $\begin{array}{c}\text { Selisih } \\
\text { terhadap } \\
\text { Nilai Kritis } x^{2} \\
\end{array}$ & Kesimpulan \\
\hline $\begin{array}{c}\text { Keberadaan } \\
\text { Ilustrasi }\end{array}$ & $\begin{array}{c}\mathrm{H}_{0} \\
\text { ditolak. }\end{array}$ & 147,2 & $\begin{array}{c}\text { Keberadaan } \\
\text { ilustrasi } \\
\text { berpengaruh. }\end{array}$ \\
\hline Warna & $\begin{array}{c}\mathrm{H}_{0} \\
\text { ditolak. }\end{array}$ & 23,84 & $\begin{array}{c}\text { Warna } \\
\text { berpengaruh. }\end{array}$ \\
\hline Gaya Bahasa & $\begin{array}{c}\mathrm{H}_{0} \\
\text { ditolak. }\end{array}$ & 2,05 & $\begin{array}{l}\text { Gaya bahasa } \\
\text { berpengaruh. }\end{array}$ \\
\hline Posisi & $\begin{array}{c}\mathrm{H}_{0} \\
\text { ditolak. }\end{array}$ & 12,42 & $\begin{array}{c}\text { Posisi } \\
\text { berpengaruh. }\end{array}$ \\
\hline Ukuran Font & $\begin{array}{c}\mathrm{H}_{0} \\
\text { ditolak. }\end{array}$ & 79,76 & $\begin{array}{l}\text { Ukuran font } \\
\text { berpengaruh. }\end{array}$ \\
\hline Lokasi & $\begin{array}{c}\mathrm{H}_{0} \\
\text { ditolak. }\end{array}$ & 107,90 & $\begin{array}{c}\text { Lokasi } \\
\text { berpengaruh. }\end{array}$ \\
\hline Jenis & $\begin{array}{c}\mathrm{H}_{0} \\
\text { ditolak. }\end{array}$ & 25,30 & $\begin{array}{c}\text { Jenis } \\
\text { berpengaruh. }\end{array}$ \\
\hline
\end{tabular}

\subsection{Saran}

Setelah melakukan penelitian ini, peneliti memiliki beberapa saran yang diharapkan dapat berguna bagi pembaca maupun pihak yang berminat untuk melakukan penelitian terhadap bidang ini.

Sebuah penelitian yang lebih sempit, dalam dan terfokus sebaiknya dilakukan untuk mengetahui efek dari salah satu dari faktor-faktor yang diteliti pada penelitian ini. Penelitian baru tersebut memang akan memakan waktu dan sumber daya yang lebih banyak namun hasilnya akan sangat bermanfaat dan mendukung hasil penelitian ini. Salah satu contohnya adalah penelitian tentang gaya bahasa terhadap efektifitas iklan online. Penelitian tersebut dapat dilakukan dengan lebih dalam dan mempertimbangkan banyak aspek namun terbatas pada area yang dibahas yaitu gaya bahasa.

Penelitian efektifitas dengan pendekatan model komunikasi sebaiknya juga dilakukan untuk mendapatkan hasil yang dapat dibandingkan dengan pendekatan jumlah klik yang diterapkan pada penelitian ini. Dengan adanya penelitian tersebut, diharapkan akan semakin luas informasi yang didapatkan.

Peneliti juga menyarankan agar penelitian pada populasi yang lebih luas dengan sampel yang lebih besar dapat dilakukan untuk mendapatkan gambaran yang semakin akurat dan mendekati dunia nyata.

Selain itu, peneliti juga menyarankan agar dilakukan penelitian dengan partisipasi dari para aktor periklanan seperti penyedia space, biro iklan, serta perusahaan pengiklan. Mereka sebaiknya terlibat langsung dalam penelitian dengan menguji sebuah kampanye iklan yang nyata serta mengukur performanya dengan terbuka untuk kepentingan penelitian.

\section{REFERENSI}

[1] Alexander, Ralph S. "Marketing Definitions." Chicago: American Marketing Association, 1965.

[2] Smith, Sidney L., dan Jane N. Mosier. "Guideliness For Designing User Interface Software.” Userlab Inc., Agustus 1986.

[3] Garson, Dave. http://www2.chass.ncsu.edu/ garson/pa765/chisq.html (accessed Juni 11, 2008).

[4] Syafrizal, Melwin. Pengantar Jaringan Komputer. Yogyakarta: ANDI, 2005.

[5] Sutherland, Max, and Alice K. Sylvester. Advertising and the Mind of the Consumer What Works, What Doesn't, and Why. New South Wales: Allen \& Unwin, 2000.

[6] Bruner, Rick E. "DoubleClick.com \| Research Report." Double Click The Nerve Center of Digital Marketing. Mei 2006. http://www.doubleclick.com/insight/downloa dResearch.aspx?fileName=dc_bpwp_0605.pd f (accessed Juni 2, 2008).

[7] Dees, Windy. Measuring The Effectiveness of Commercial Sponsorships in Intercollegiate Athletic. Master Thesis, Florida: University of Florida, 2004.

[8] Ship, Terence A. Integrated Marketing Communications in Advertising and Promotion. Thomson South-Western, 2007. 